\title{
Do IMF and World Bank Programs Induce Government Crises? An Empirical Analysis
}

\author{
Axel Dreher and Martin Gassebner
}

\begin{abstract}
We examine whether and under what circumstances World Bank and International Monetary Fund (IMF) programs affect the likelihood of major government crises. We find that crises are, on average, more likely as a consequence of World Bank programs. We also find that governments face an increasing risk of entering a crisis when they remain under an IMF or World Bank arrangement once the economy's performance improves. The international financial institution's (IFI) scapegoat function thus seems to lose its value when the need for financial support is less urgent. While the probability of a crisis increases when a government turns to the IFIs, programs inherited by preceding governments do not affect the probability of a crisis. This is in line with two interpretations. First, the conclusion of IFI programs can signal the government's incompetence, and second, governments that inherit programs might be less likely to implement program conditions agreed to by their predecessors.
\end{abstract}

There is substantial anecdotal evidence that structural adjustment programs by the World Bank and the International Monetary Fund (IMF) face severe resistance from groups in society that fear the negative consequences of the programs. ${ }^{1}$ In some cases IMF and World Bank programs have led to government crises, cabinet changes, or the replacement of entire governments. However, there are also countries in which the implementation of adjustment programs did not result in major political turmoil. What are the circumstances under which IMF and World Bank programs harm the governments of the program countries, and when is it that international financial institutions (IFIs) do not cause government crises? While several studies allude to empirical evidence showing that IMF programs affect survival rates of political leaders, ${ }^{2}$ this question has yet to be properly investigated.

We thank Richard Jong-A-Pin for contributions to an earlier draft of this article as well as James Vreeland, seminar participants at Yale University, the University of Birmingham, the First Conference on the Political Economy of International Organizations (Monte Verità, 2008), the 2008 conference of the Research Committee Development Economics of the German Economic Association and the reviewers of this journal for helpful comments, and Stefanie Walter and Thomas Sattler for providing their data on fixed exchange rate collapses. We thank Scott Jobson for proofreading. Supplemental material for this article can be found at www.journals.cambridge.org/ino2012007.

1. For an extensive list of IMF- and World Bank-induced riots, see Caffentzis and Federici 2001.

2. See, for example, Killick 1995; Smith and Vreeland 2006; and Dreher 2004.

International Organization 66, Spring 2012, pp. 329-58

(C) 2012 by The IO Foundation.

doi:10.1017/S0020818312000094 
The question's answer could guide governments on the verge of concluding IMF and World Bank programs. The answer might also help IFIs design their programs in a way that does not harm program countries' governments. To some extent, knowing the circumstances leading to government crises also sheds light on the IFIs' "scapegoat" function. ${ }^{3}$ Can governments blame the IFIs for unpopular policies and thereby reduce the risk of crises? Or do citizens blame their government for the IFIs' presence and respond with riots and demonstrations, leading to government crises?

We first examine whether the implementation of IMF and World Bank programs on average induces government crises. Next, we investigate the circumstances that yield negative outcomes and separate those from cases in which the IMF and World Bank did not hurt-or even helped-the governments. We find that World Bank programs significantly increase crisis probability, on average. We also find that governments face an increasing risk of entering a crisis when they remain under an IMF or World Bank program once the economy improves. While crisis probability rises when a government turns to the IFIs, programs inherited by preceding governments do not affect the probability of a crisis. These results are in line with two explanations, with rather different policy implications. First, instability might increase because program terms are onerous and damage the economy, thereby creating a situation that threatens government survival. ${ }^{4}$ Second, crises might occur because the program reveals the poor quality of government policies. The explanation is suggested by a signaling model $^{5}$ - the conclusion of IFI programs can signal the government's incompetence in certain situations. This is because competent politicians do not have to turn to the IFIs for credit when the economy performs moderately poor, while incompetent governments do.

\section{The Hypotheses}

The record of IMF and World Bank programs cannot be considered fully successful. ${ }^{6}$ It is therefore no surprise that the political costs of negotiating IMF and World Bank programs can be substantial. ${ }^{7}$ There are a number of ways in which the IFIs' programs may influence policies and outcomes in the recipient country, thereby affecting the probability of government crises. The IFIs are frequently accused of

3. Vreeland 1999.

4. However, we also observe that inherited programs do not hurt the government. If governments that inherit programs are less likely to implement program conditions agreed to by their predecessors (or the IFIs are less likely to insist on implementation), inherited programs could be less damaging to governments.

5. Dreher 2004.

6. See, for example, Vreeland 2003 and 2006; Steinwand and Stone 2008; and Marchesi and Sirtori 2011.

7. Vreeland 1999. For a recent analysis on what determines the size of IMF loans see Moser and Sturm 2011. 
imposing conditions that imply market-oriented policies. For example, a frequent condition for World Bank adjustment lending is the reduction of price distortions or the elimination of subsidies. ${ }^{8}$ The IMF usually asks for restrictive fiscal and monetary policy, currency devaluations, and the reduction of subsidies. While the implementation of these conditions might be beneficial for long-run economic growth, such policies can hurt a large number of people in the short term. Even when the majority of a government endorses the program and is willing to implement the policies, other parts of the government might see their constituents being hurt by the programs and therefore refuse the IFIs' conditionality in order to protect their constituencies and increase their popularity. This can give rise to dissent among the government. Some groups of the government coalition might threaten to leave, potentially inducing a political crisis. There is ample anecdotal evidence showing that IMF and World Bank conditions have provoked protests, occasionally leading to government crises.

However, conditionality can also reduce the risk of a crisis. It can change political power constellations. This is likely to be true both within government and for parties among the parliament in general. Within the government, it is well documented that finance and economy ministers' positions are strengthened vis-à-vis the spending ministries. ${ }^{9}$ The minister of finance is usually more interested in restrictive fiscal policies compared to the spending ministries. ${ }^{10}$ In times of economic hardship, this will likely lead to tensions within the government, increasing the risk of crises. To the extent that the IFIs' conditions tie the disbursements of their money to restrictive policies, the finance minister can use them as a scapegoat for such policies. This strengthens this official's position and might prevent a crisis. ${ }^{11}$

The IFIs' scapegoat function can also help in securing power for the government. ${ }^{12}$ Consider the example of Brazil. In 1998 President Fernando Cardoso negotiated an IMF arrangement despite the ample availability of foreign reserves. The Cardoso government favored substantially restructuring the government's budget which faced severe opposition, even within its own coalition. ${ }^{13}$ By tying his policies to the IMF program, Cardoso was able to overcome domestic opposition. As Cardoso put it, "The whole world is watching us, watching to see if we'll be able to resolve the crisis." ${ }^{14}$ By tying their hands to the IFIs' program, a government in favor of restrictive policies can thus overcome resistance and hence reduce the probability of a political crisis.

Another channel through which the IFIs can affect political crises is the funds associated with their programs. Ideally, conditionality prevents abuse of the loans,

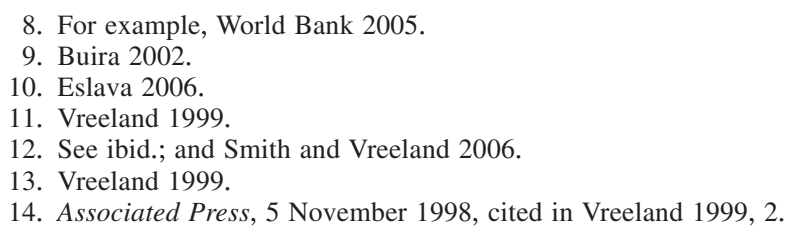


so that the loans can be used to alleviate economic hardship. The World Bank's Structural Adjustment Loans can provide governments with the money they need for the temporary financing of restructuring measures. The IMF can provide international reserves to pay for imports that are required for domestic production. This should reduce the risk of a government crisis.

However, when conditionality fails, IMF and World Bank loans increase a government's leeway, potentially reducing the IFIs' role as a scapegoat. If the increased leeway is used to postpone necessary reforms, a government crisis might be deferred but could still eventually hit even harder. The probability of a crisis would then increase with loan size. On the other hand, without effective conditionality the loans could be directly used by national governments to secure power. ${ }^{15}$ Loans from the IMF and the International Bank for Reconstruction and Development (IBRD) are significantly larger in preelection periods, facilitating the generation of political business cycles. ${ }^{16}$ We assume that governments make use of the IFIs' money to secure their power not only at election time, but whenever they deem it necessary. To the extent that support gained with the help of IFI credit outweighs the loss of support due to program implementation, the likelihood of a government crisis is reduced.

Based on these considerations, the direction of IMF and World Bank programs or loans on the probability of crises is not a priori obvious. However, the effect of IMF and World Bank programs is likely to depend on the circumstances under which a program came into effect. ${ }^{17}$ The argument can be demonstrated in a signaling model. ${ }^{18}$ According to the model, the IFIs' programs can help citizens to "read" the "type" of their government under certain circumstances. The model assumes that competent politicians do not have to turn to the IFIs if the economy performs moderately, but incompetent governments do. Competent politicians can thus highlight their competence by borrowing from the market or other countries, while incompetent politicians borrow from the IFIs, thereby signaling their incompetence. Arguably, domestic support for the government is likely to suffer once incompetence becomes apparent, potentially giving rise to government crises. An empirical test of the model shows that governments concluding IMF arrangements prior to a national election generally increase their reelection probability. ${ }^{19}$ However, this increased probability of reelection following the conclusion of programs decreases in the face of rising GDP growth. IMF and World Bank programs might thus indicate the incumbent's quality: when growth rates are low, voters accept the necessity of the IFIs' involvement. In a good economic environment, however, only incompetent governments need their assistance - they consequently lose office in the next election.

15. Dreher and Vaubel 2004.

16. Ibid.

17. Smith and Vreeland 2006.

18. Dreher 2004.

19. Ibid. 
Arguably, the effect of IMF and World Bank involvement on government crises is also likely to depend on the program's success and the economy's development. For our purposes, it does not matter whether, and to what extent, the IFIs caused such development. An increase in economic growth for example, may be attributed to the IFIs' programs regardless of whether these programs actually caused growth. When a program turns out to be successful, people might be more inclined to accept short-term losses for expected future benefits. The probability of entering a crisis should thus decrease.

Government survival might not be in danger if IMF programs are already in effect when the current government comes to power. ${ }^{20}$ In this case, citizens do not blame their government for the program's existence. As Smith and Vreeland argue, the incumbent government can use the IMF as a scapegoat given that it is not directly responsible for the program. Consequently, resistance to the government, and thus instability, decreases. However, when the economy performs well, the IFIs' scapegoat function can lose its significance. The threat of terminating the programs is not as binding for opposing views in or outside the government as it is in harder times. On the contrary, when the economy performs badly, opponents of the current policy stance are more likely to accept some economic hardship. The IFIs' policy conditions will then continue to reduce the probability of government crises. In light of the signaling model, inherited programs might not be useful in "reading" the current government's competence. Even competent governments might stick with the programs if the economy performs badly. If economic performance improves, however, citizens might take the persistence of the program as a signal of their government's incompetence.

We derive two hypotheses from this discussion:

H1: The effect of IMF and World Bank involvement on crisis probability depends on the state of the economy.

H2: The effect of IMF and World Bank programs on crisis probability depends on whether the current government turned to the IFIs itself, or inherited the program.

In testing these two hypotheses, we can potentially discriminate between alternative channels that link IFI programs to government crises. If we find evidence that programs do not hurt governments when they are economically successful this would imply that voters might be willing to accept short-term hardship for longerterm benefits. If we find it does hurt governments, such evidence would be in line with the argument that IFI programs can be used by voters to infer the competence of politicians. ${ }^{21}$ Evidence in line with $\mathrm{H} 2$ would provide further support for the signaling model.

20. Smith and Vreeland 2006.

21. Dreher 2004. 


\section{Method and Data}

The IFI's presence in a country has quite a diversity of effects on crisis probability and it seems difficult to find equivalents for them in terms of observable variables. We follow Boockmann and Dreher who suggest the number of programs in operation as a proxy measuring the pressure for reforms. ${ }^{22}$ This is due to either the direct effect of conditionality on policies, or the transfer of knowledge and advice, which increases with the number of contacts between a recipient country and the IMF or World Bank. We would like to measure contacts directly to distinguish between conditionality, transfer of knowledge, or other informal effects, but we lack the data to do so. To capture the softening of the budget constraint, it is necessary to include financial variables. In principle, the amount of IMF or World Bank credit a country receives may also proxy the direct effect of conditionality on national policies. However, conditions and credit volumes need not be proportional, and some conditions are included in almost all programs. ${ }^{23}$ Thus, the number of arrangements concluded may be a better measure for IFI conditionality than the flow of finances. Controlling for the programs in operation, the amount of credit should be insignificant if there is no effect of the softening of the budget constraint, should increase the probability of a crisis if reforms are postponed as a consequence of the softening of the budget constraint, or should reduce the risk of crisis if the money is directly used to maintain power.

We employ seven variables indicating IMF and World Bank involvement in a country. We use dummy variables that are equal to 1 , if an IMF program has been in effect for at least five months of a certain year, and 0 otherwise. One dummy includes programs under the IMF's Structural Adjustment Facility and Poverty Reduction and Growth Facility (SAF/PRGF) and a second includes programs under its Stand-by Arrangement (SBA). ${ }^{24}$ We use a similar variable for the World Bank, counting the number of loans given for structural adjustment in effect for at least five months in a certain year, according to the definition from the World Bank's web page. ${ }^{25}$ While countries can have only one IMF program operating at a time under the facilities covered here, the maximum number of World Bank structural adjustment programs among the countries in our sample is seven (Bangladesh in 1989 and Argentina in 1998 and 1999). To measure the effect of the IFIs' loans we

22. Boockmann and Dreher 2003.

23. According to Marchesi, Sabani, and Dreher 2011, IMF credits disbursed reduce rather than increase the number of conditions in a program. Higher loans do not seem to come with tougher conditionality. This result is in line with Drazen 2002, showing that fewer conditions are required for larger loans, since the government will find it easier to remunerate lobbies and veto players in exchange for reforms with larger loans.

24. We use these facilities separately rather than jointly and let the data decide on whether or not their effect on crises is the same.

25. Available at 〈www.worldbank.org/projects/〉, accessed 15 October 2011. 
use gross disbursements as a percentage of GDP. ${ }^{26}$ Regarding the IMF, we again distinguish flows under the SAF/PRGF from those of the SBA. For the World Bank, disbursement data on structural adjustment loans are not available. We therefore use disbursements from the IBRD and-separately-the International Development Agency (IDA). ${ }^{27}$

The regression is a pooled time-series cross-section analysis. Our annual data cover the 1970-2002 period and extend to a maximum of 132 developing countries. $^{28}$ Since some of the data are not available for all countries or years, the panel data are unbalanced and the number of observations depends on the choice of explanatory variables. ${ }^{29}$ Our dependent variable is a dummy, taking the value of 1 in the case of at least one major government crisis having occurred and 0 otherwise. A major government crisis is defined as "any rapidly developing situation that threatens to bring the downfall of the present regime, excluding situations of revolt aimed at such overthrow." 30 The variable is frequently used as a measure of instability in the empirical literature. ${ }^{31}$

To estimate the impact of World Bank and IMF programs on the probability of major government crises, we use a conditional fixed-effects logit model including three cubic splines along with a count variable for the number of years since the last major government crisis to correct for temporal dependence. ${ }^{32}$

As a potential problem, IMF and World Bank programs might be triggered by the same set of underlying factors that also trigger a government crisis. When we fail to explicitly control for these factors, our results might reflect some common cause interdependency and would as such be spurious. IMF and World Bank programs might even be directly affected by government crises. It needs to be noted, however, that endogeneity is likely to bias the estimated effect of IMF and World Bank programs downward. Arguably, demand for programs is lower when governments expect them to lead to a political crisis. Along the same lines, supply of IMF and World Bank money will be lower if there is government instability, since we would expect compliance with the IFIs' conditionality to be lower when the government that signed the contract loses office. The estimated coefficients are thus likely to represent the lower bound of the IFIs' impact on government crises.

26. The sources are the IMF's web page on country information $\langle w w w . i m f . o r g / e x t e r n a l / c o u n t r y /\rangle$, and annual reports 〈http://www.imf.org/external/pubs/ft/ar/index.htm $\rangle$, for the IMF's disbursements; and the Global Development Finance database 〈http://data.worldbank.org/data-catalog/globaldevelopment-finance $\rangle$, for the World Bank's disbursements; while gross domestic product (GDP) data are taken from World Bank 2006. Websites accessed 1 November 2011.

27. We test for the robustness of our results using commitment data on structural adjustment loans. The results are unaffected.

28. We omit industrialized countries that have never received IMF or World Bank loans.

29. All variables, their precise definitions, data sources, and summary statistics are listed in Appendixes 1 and 2 .

30. The source is Databanks International 2005.

31. For example, Broz 2002.

32. Beck, Katz, and Tucker 1998. 
Addressing the potential endogeneity problem formally, we use two strategies. First, we use maximum likelihood instrumental variables probit techniques with standard errors clustered at the country level. As our first instrument we use a country's voting behavior in the United Nations (UN) General Assembly, which is a standard measure employed in the recent literature. The empirical literature regarding political influences on the IFIs shows that developing countries get better terms from the IFIs when they have closer ties with the United States, as measured by their voting behavior in the UN General Assembly. ${ }^{33}$ We code votes in agreement as 1 , votes in disagreement as 0 , and divide by the total number of votes in a particular year. ${ }^{34}$ Arguably, although related to the probability of receiving money from the World Bank and IMF, UN General Assembly voting is unlikely to be correlated with government crises directly. As a second instrument we propose the debt-to-GDP ratio, calculated as the share of public and publicly guaranteed debt in GDP. ${ }^{35}$ Obviously, debt increases the probability that a government turns to the IFIs. ${ }^{36}$ However because the debt-to-GDP ratio is not a direct determinant of government crises, it is a suitable instrument. ${ }^{37}$ This is also reflected in the simple correlation between debt and crises that is almost zero in our sample. As an alternative to the IV probit, we replicate the analysis using a dynamic panel generalized method of moments (GMM) approach. ${ }^{38}$

\section{Empirical Results}

We replicate the analysis of Gassebner and Jong-A-Pin, adding our variables of interest to their model. ${ }^{39}$ Using a general-to-specific approach and extreme bounds analysis, they examine which variables are robustly related to major government crises. These robust variables are: the type of political regime and its duration, several (logged) variables proxying for political violence (guerilla warfare, assassinations, and purges), and mass civil protest (demonstrations, riots, and general strikes) as well as economic growth per capita. Given the large number of additional, potentially important variables they tested, we can be reasonably confident that our model does not suffer from omitted variables bias. ${ }^{40}$

33. See, for example, Kilby 2009 and 2011.

34. We follow Dreher and Sturm 2012, in constructing a variable reflecting the average vote of the Group of 7 (G7) countries, then weighting each G7 country's vote with its quota in the IMF to take its voting weight in the international organization into account. We discard abstentions and absences.

35. The source is World Bank 2006.

36. For example, Marchesi and Sabani 2007.

37. Gassebner and Jong-A-Pin 2007.

38. As a way of minimizing the number of instruments in the regressions, we collapse the matrix of instruments. The Hansen test and Arellano-Bond test do not reject our model.

39. Gassebner and Jong-A-Pin 2007.

40. Ibid. Note that we control for inflation, international reserves, and the current account balance below. We also included official development aid (as a percentage of GDP), GDP per capita, and a 
Specifications 1 to 7 of Table 1 test for the effect of the IMF and World Bank variables using conditional fixed-effects logit. Column (1) includes the number of World Bank programs, while column (2) includes IMF Structural Adjustment Facility/Poverty Reduction and Growth Facility (SAF/PRGF) and SBA programs for the whole sample period. We should note, however, that the IMF's SAF was created in 1986, so the observations prior to 1986 are all set to 0 here. In column (3), we show the same specification restricted to the 1986 to 2002 period. Columns (4) and (5) replicate these specifications, including the IMF and World Bank variables jointly rather than separately. In columns (6) and (7), we add gross disbursements to the program variables.

The results suggest that major government crises are more likely in more democratic political systems. Parties in such systems can easily express their opinion on controversial policies and events that may ultimately trigger a crisis. We find crises to be significantly more likely when mass civil protest and political violence exists, represented by the highly significant coefficients of demonstrations and purges (while the coefficients of riots, strikes, assassinations, regime duration, and guerilla warfare are not robustly significant at conventional levels). Moreover, economic growth in the previous year reduces the likelihood of a government crisis, at the 1 percent level of significance.

Turning to our variables of interest, the probability of government crises is strongly affected by World Bank programs. According to column (1), World Bank programs increase the probability of a crisis at the 1 percent level of significance. The corresponding marginal effect implies that each World Bank structural loan received in the previous year increases the probability of a major government crisis by 5.4 percent. ${ }^{41}$ The coefficient remains similar in magnitude in columns (4) and (5), remaining significant at the 5 percent level when IMF programs are also included in the full sample, and at the 10 percent level when the sample is restricted to the 1986 to 2002 period. Compared to the quantitative effect of a World Bank project, the effect of an SAF/ PRGF program seems to be even larger. According to column (2), the estimated coefficient is significant at the 5 percent level, while the corresponding marginal effect suggests that an SAF/PRGF program in the previous year increases the probability of a major government crisis by 15.1 percent. The effect of Stand-by Arrangements is not significant at conventional levels, and significantly smaller compared to the effect of the IMF's concessional loans (at the 10 percent level). ${ }^{42}$

dummy for currency crises. The coefficients of the additional variables are not significant at conventional levels and our results of interest are unchanged.

41. All marginal effects are estimated at the mean of all explanatory variables, setting the fixed effects to 0 .

42. Note that the coefficient becomes marginally significant in column (3). However, the coefficient remains significantly smaller compared to those of SAF/PRGF programs and is not robust to the inclusion of the disbursement variables. 


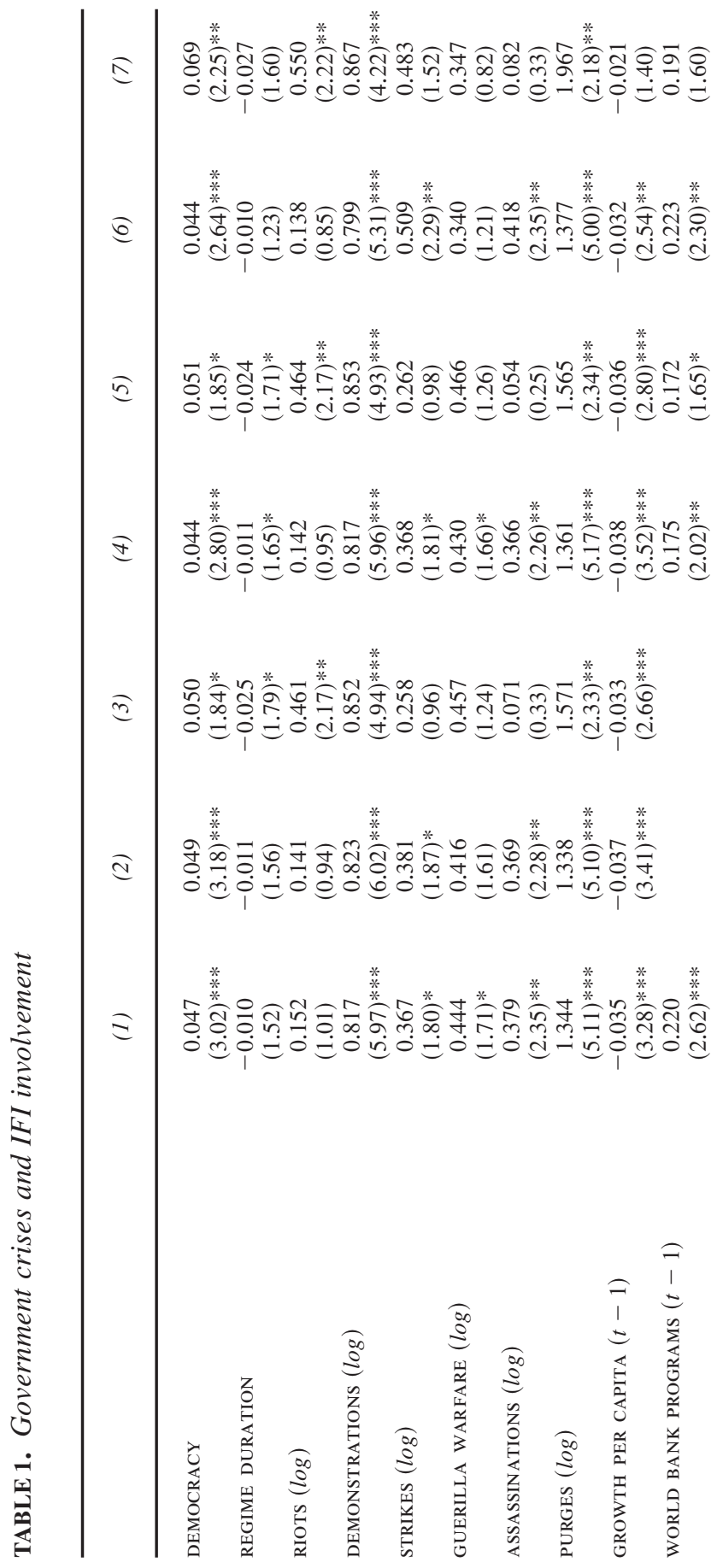




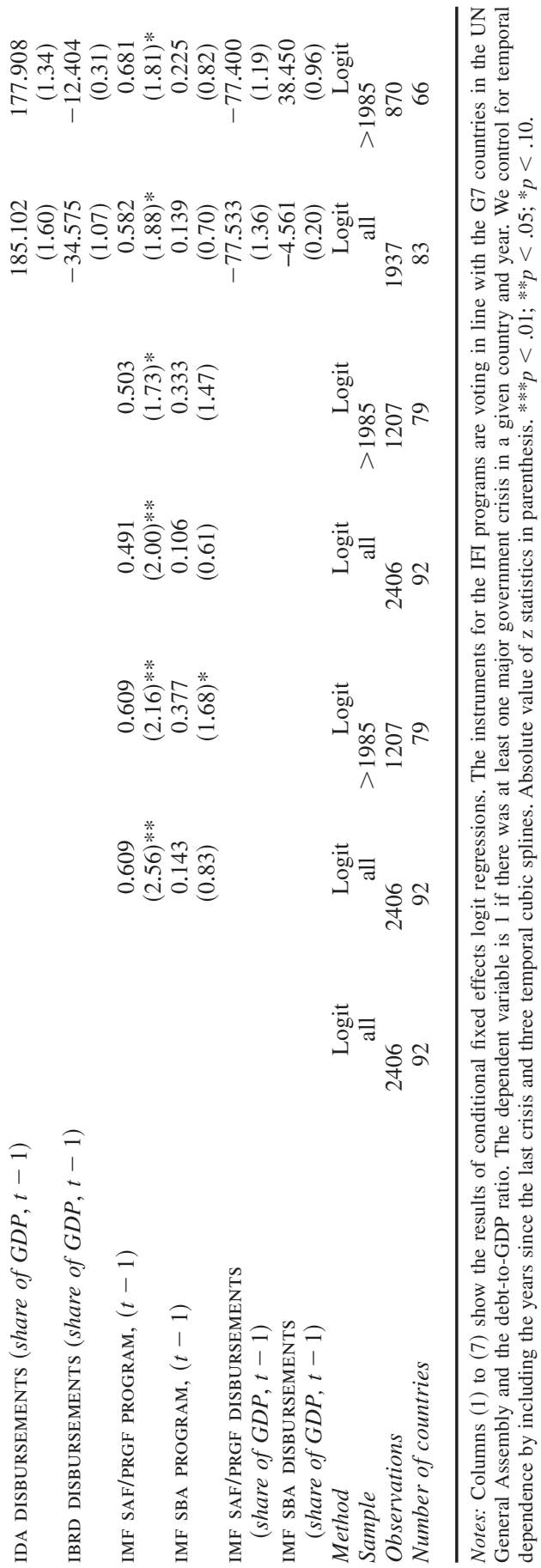




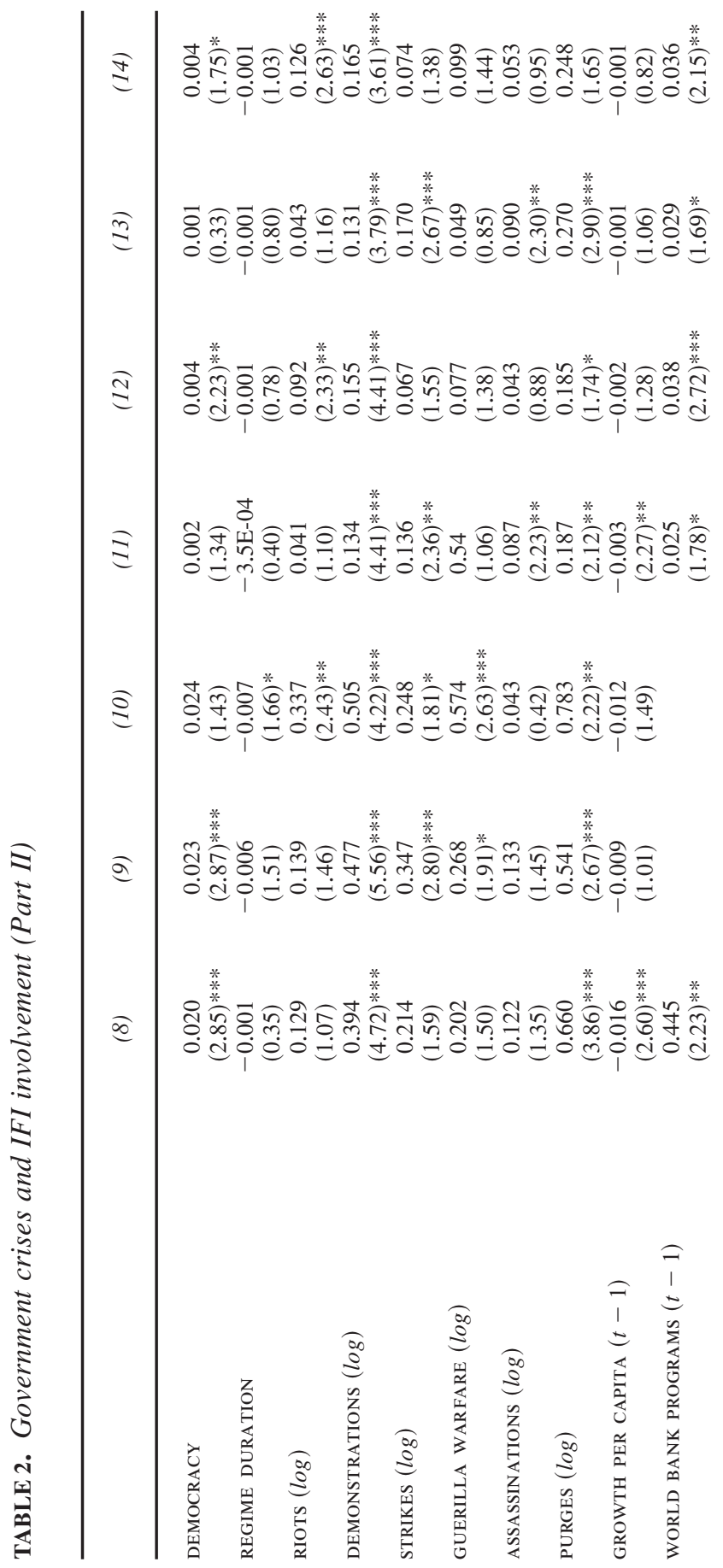




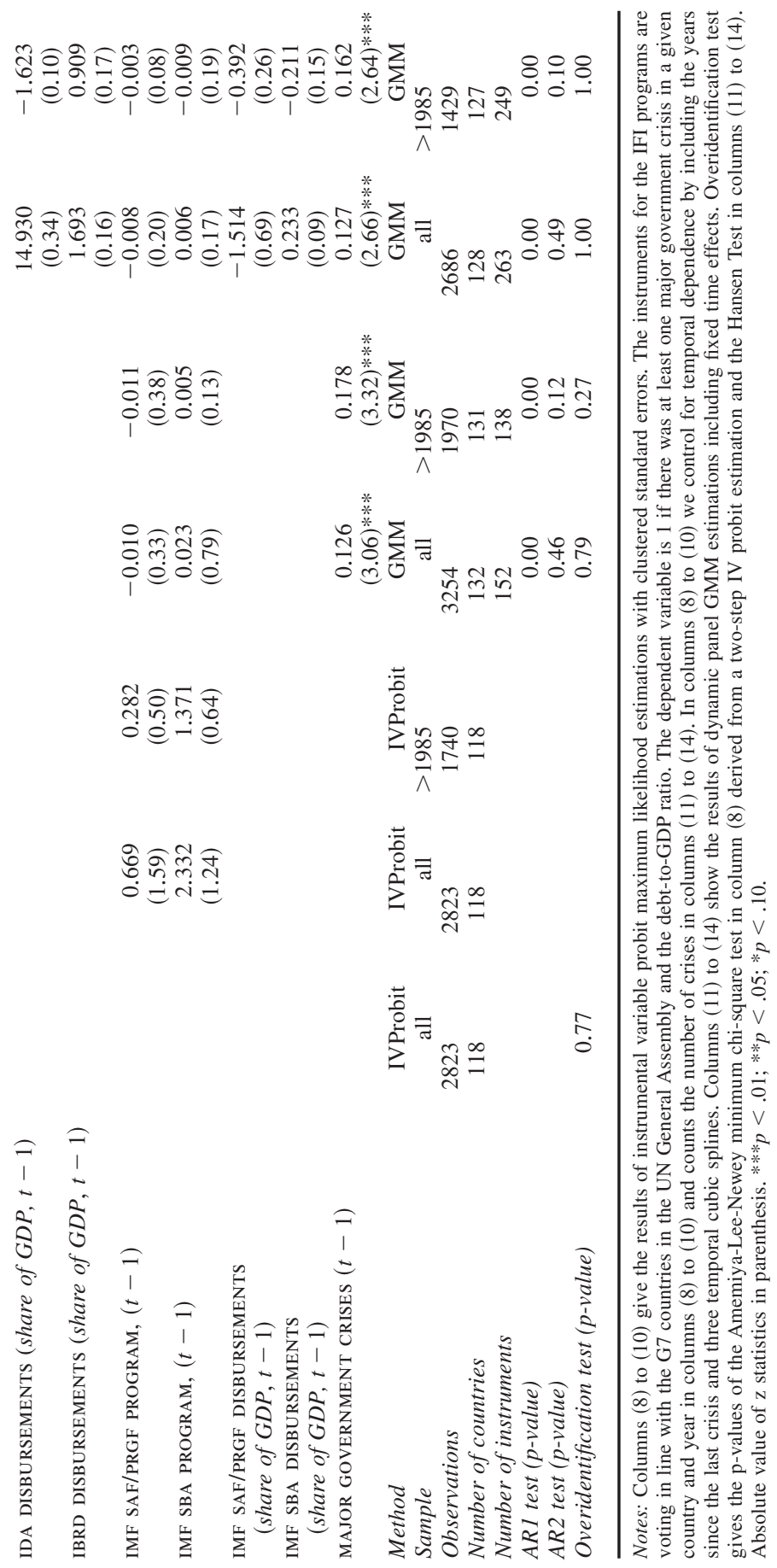


When including the IMF and World Bank variables in tandem (column 4), the corresponding marginal effects change to a probability increase of 4.3 percent for a World Bank project and 12.2 percent for an SAF/PRGF program. When including gross disbursements, the program variables are significant at the 10 percent level at least in the full sample (column 6). While the coefficient of World Bank programs becomes marginally insignificant in column (7) (p-value 0.109), the coefficient remains very similar when compared to column (6). Gross disbursements are not significant at conventional levels in either specification, however. Our results therefore show that conditionality and advice seem to be more important than loan size in affecting government crises. On average, the effect of restrictive policies prescribed by the IFIs seems to outweigh the effects of the stronger position of the finance minister and the "scapegoating" effect.

Columns (8) to (10) in Table 2 show the results of the IV probit estimations. Although we would like to include the IMF and World Bank variables in the same specification, we have only two instruments for three potentially endogenous variables, so we are forced to use the IFI variables separately. For the same reason, we cannot include gross disbursements in addition to the program variables. ${ }^{43}$ Note here, that our instruments are not rejected; the test for overidentification shows that they are uncorrelated with the error term (but it can be conducted in only the World Bank specification given that there is no overidentification with the two separate program variables for the IMF). Finally, our instruments are not weak either-the first stage F-value easily exceeds the critical threshold of $10 .^{44}$

The results for the World Bank are confirmed. After controlling for potential endogeneity, World Bank programs trigger major government crises. The magnitude of the effect is comparable with the conditional fixed-effects logit setup: an additional World Bank program increases the likelihood of a crisis by 6.8 percent (column 8). However, the coefficients of the IMF's (SAF/PRGF and SBA) programs are not significant at conventional levels in any of the additional regressions.

Columns (11) to (14) in Table 2 report the results obtained by employing the GMM estimator. One drawback of this setup is that the resulting coefficients can no longer be interpreted as probabilities. Note that the lagged dependent variable is significant at the 1 percent level, with a positive coefficient confirming our findings from the temporal dependence setup. Column (11) shows the overall sample, excluding disbursements. In column (12), we restrict the sample to the 1986 to 2002 period. Columns (13) and (14) replicate these regressions including disbursements.

The results show that the number of crises increases with the number of World Bank programs, at least at the 10 percent level of significance. The IMF program dummies, however, are insignificant at conventional levels. Gross disbursements

43. When we include disbursements instead of programs the coefficients are not significant at conventional levels.

44. Staiger and Stock 1997. 
are also not significantly related to government crises in any specification. ${ }^{45}$ Following the interpretation of Boockmann and Dreher outlined earlier, controlling for the amount of money, the existence of the program itself is likely to reflect conditions and advice. The effect of the World Bank therefore seems to be more related to conditions and advice than moral hazard.

We next turn to testing our two hypotheses. In order to test $\mathrm{H} 1$, we replicate the analysis including proxies for the contemporary state of the economy. We thereby assume that people judge the role of the IFIs based on recent economic developments and their interactions with IMF and World Bank programs. We focus on the IMF's SAF/PRGF programs and programs by the World Bank given the insignificance of the IMF's Stand-by Arrangements and the disbursement variables. ${ }^{46}$

We use the following variables: economic growth per capita, consumer price index, current account balance, foreign reserves measured in months of imports, ${ }^{47}$ as well as the degree of IFI involvement in a country's respective region. ${ }^{48} \mathrm{We}$ calculate the degree of IFI involvement by taking averages of the number of World Bank and IMF programs being carried out in the specific geographical region of the said country (excluding the country under focus, so there is variation within the regions). ${ }^{49}$

In addition to including the state of the economy variables themselves, we add their interaction with the IFIs' programs (all lagged by one year). Table 3 shows the GMM estimates, where we include the proxies for the state of the economy and their interaction with World Bank programs to the model of Table $1 .^{50} \mathrm{We}$ also estimate the same regressions using logit. ${ }^{51}$ It is important to note, however, that interpreting the interaction effect in nonlinear models (such as conditional fixed-effects logit) is not analogous to linear models. A t-test on the coefficient of the interaction term is not sufficient to test for the significance of the interaction. ${ }^{52}$ Since the t-statistics of the interaction terms are meaningless in the logit regressions, we do not report the results in a table but calculate the derivatives with respect to the variables of interest.

45. Note that although we collapse the instrument matrix, the number of instruments exceeds the number of countries in our sample. The results have to be treated with caution.

46. Including these variables as additional covariates or as additional interaction terms yields insignificant coefficients and leaves the results reported here qualitatively unchanged. These additional results are available on request.

47. The source is World Bank 2006.

48. We have also used money and quasi money growth taken from World Bank 2006 and a dummy for a fixed exchange rate collapse taken from Sattler and Walter 2010. However, both variables and their interactions with the IFIs turned out to be statistically insignificant.

49. Specifically, we distinguish the following regions: Asia (combining East Asia and Pacific, and South Asia), Europe (that is, Europe and Central Asia), Latin America, Middle East and North Africa and Sub-Saharan Africa.

50. We treat the lagged dependent variable, the IFI variable, the interacted variable, and the proxy for the state of the economy as endogenous.

51. We do not report estimates using IV probit given that we lack proper instruments for the interacted variables.

52. See Ai and Norton 2003; and Greene 2010. 


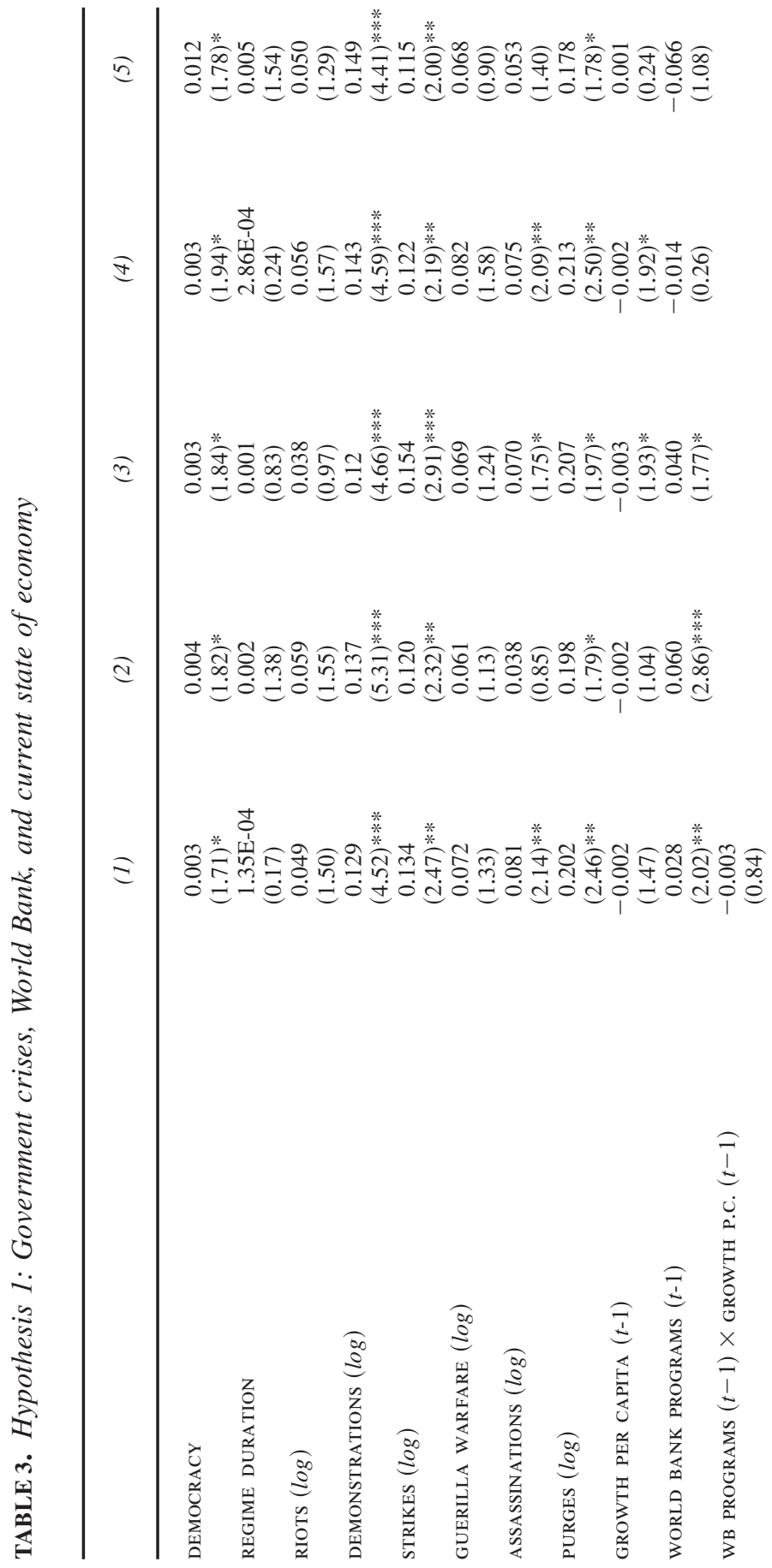




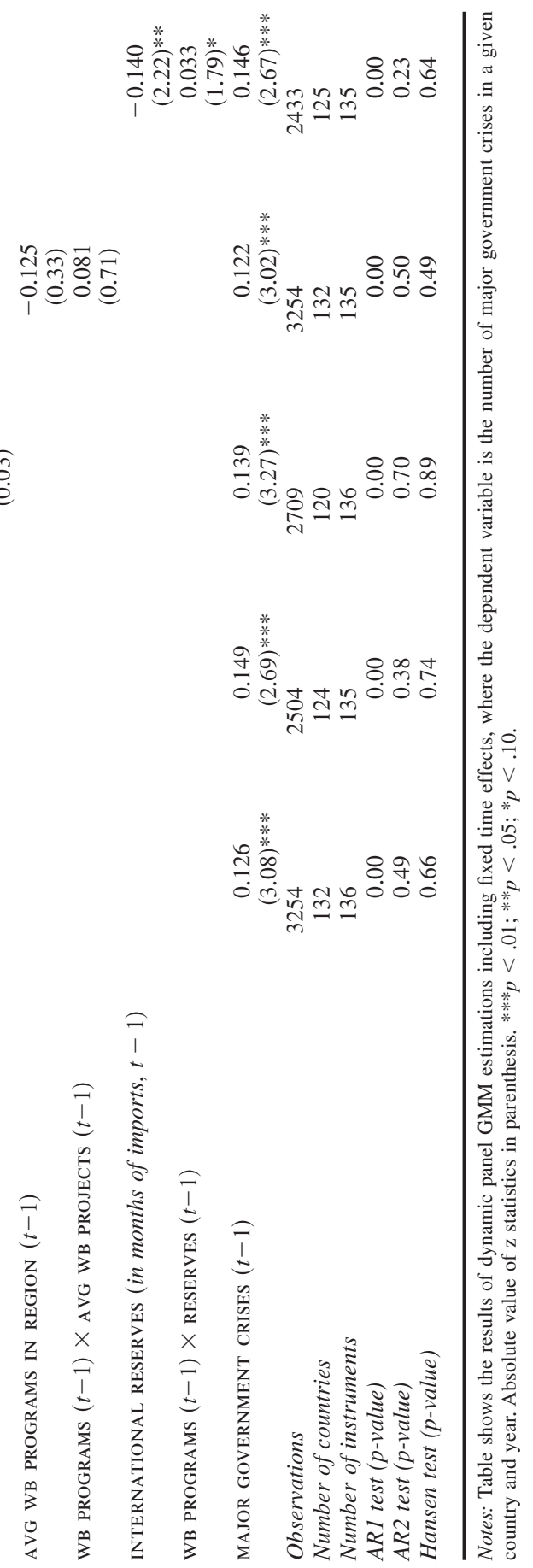


According to the results of the logit estimations, the interaction of World Bank programs with most of our proxies is not significant at conventional levels. The exception is INTERNATIONAL RESERVES, where the interaction effect is significant for a substantial share of the observations. We also conduct a likelihood-ratio test to examine whether the fit of our model improves when including the interaction terms with international reserves. ${ }^{53}$ Indeed, the test suggests that statistical fit improves $(p$-value $=.067)$. We thus conclude that the interaction between World Bank loans and international reserves affects the probability of government crises. However, we are not interested in the interaction effect as such, but in the marginal effect of a World Bank project. Because the values of all variables influence the marginal effect and this effect is conditional on the level of international reserves, we show the result in Figure 1. As can be seen, for very low reserve levels, the effect of the World Bank is not statistically different from 0 . Accordingly, in bad economic situations, World Bank programs do not increase the probability of a government crisis. This is in line with a potential scapegoat function of the World Bank. Unpopular policies can be attributed to the World Bank when countries need its support, increasing cohesion among the government. If reserves are above a certain threshold (in our case approximately 2.9 months of imports), an additional World Bank project increases the probability of a crisis (at least at the 10 percent level). The largest marginal effect is an increase of almost 20 percent, while the average significant effect is around 6 percent. Consequently, the scapegoat function seems to lose its value when reserves are sufficiently high and the need for World Bank support is less urgent. Arguably, citizens can "read" how their government is doing from whether or not it turns to (or sticks with) the World Bank even though reserves are high. Incompetent governments lose support and crises become more frequent.

Note that the GMM results shown in column (5) of Table 3 support this interpretation. At the 10 percent level of significance, World Bank programs increase the risk of a crisis when reserves are high, while international reserves in general decrease the probability of a crisis at the 5 percent level of significance. To calculate the marginal effect of an additional project, we again have to take both the conditioning variable (international reserves) and the interaction term into consideration. This is not only true for the magnitude of the effect but also for the significance level. In accordance with our results of the conditional fixed-effects logit setup, an additional World Bank project increases the probability of a crisis (at the 10 percent level at least) when international reserves are greater than 2.9 months of imports. In the GMM setup, the magnitude of this effect is much larger, which is due to the fact that it does not represent a probability, but rather counts the number of crises. Hence, the marginal effect is not restricted to being less than 1 .

53. As proposed by Greene 2010 . 


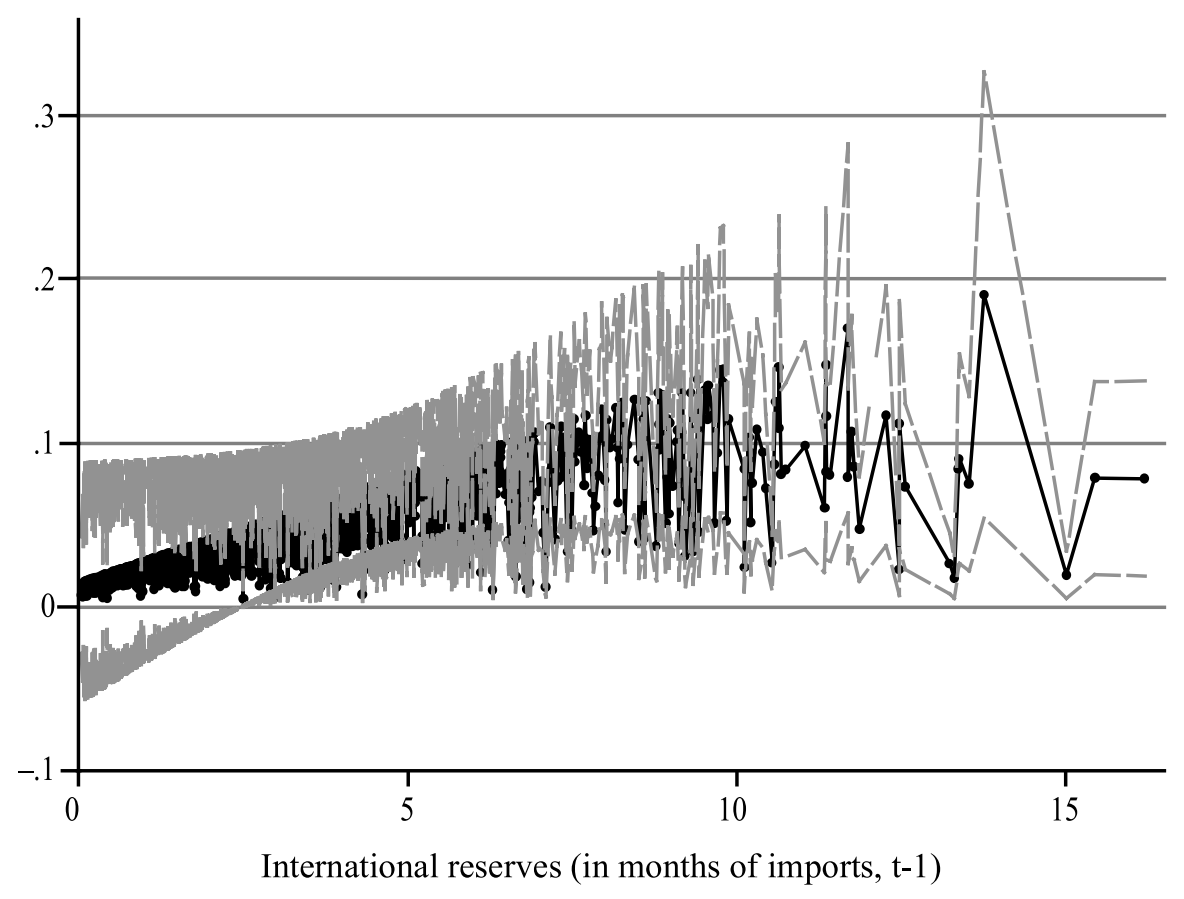

Notes: Figure shows the marginal effect of World Bank programs conditional on international reserves for the conditional fixed effects logit setup. Each dot represents the marginal effect for one observation. Also shown is the 90 percent confidence interval for each marginal effect. Country fixed effects are set to zero.

FIGURE 1. Hypothesis 1: Government crises, World Bank, and current state of economy

The GMM estimates from Table 3 show that the result for international reserves also holds for the current account balance. At the 1 percent level of significance, the interaction between World Bank programs and the current account balance increases the probability of government crises, while the current account balance itself is not significant at conventional levels. The interaction term is statistically highly significant, but the coefficient is so small that the marginal effect is virtually constant (at 6 percent).

Replicating the analysis for the IMF yields statistically insignificant interaction terms according to the logit estimates. However, as column (3) of Table 4 shows, the interaction between inflation and IMF programs is significant at the 10 percent level in the GMM setup, with a negative coefficient (with inflation itself not being significant at conventional levels). The result supports our hypothesis, indicating that the IMF's scapegoat function has greater value during times of economic hardship. With rising inflation, government crises are less likely to arise as a consequence of IMF programs. 


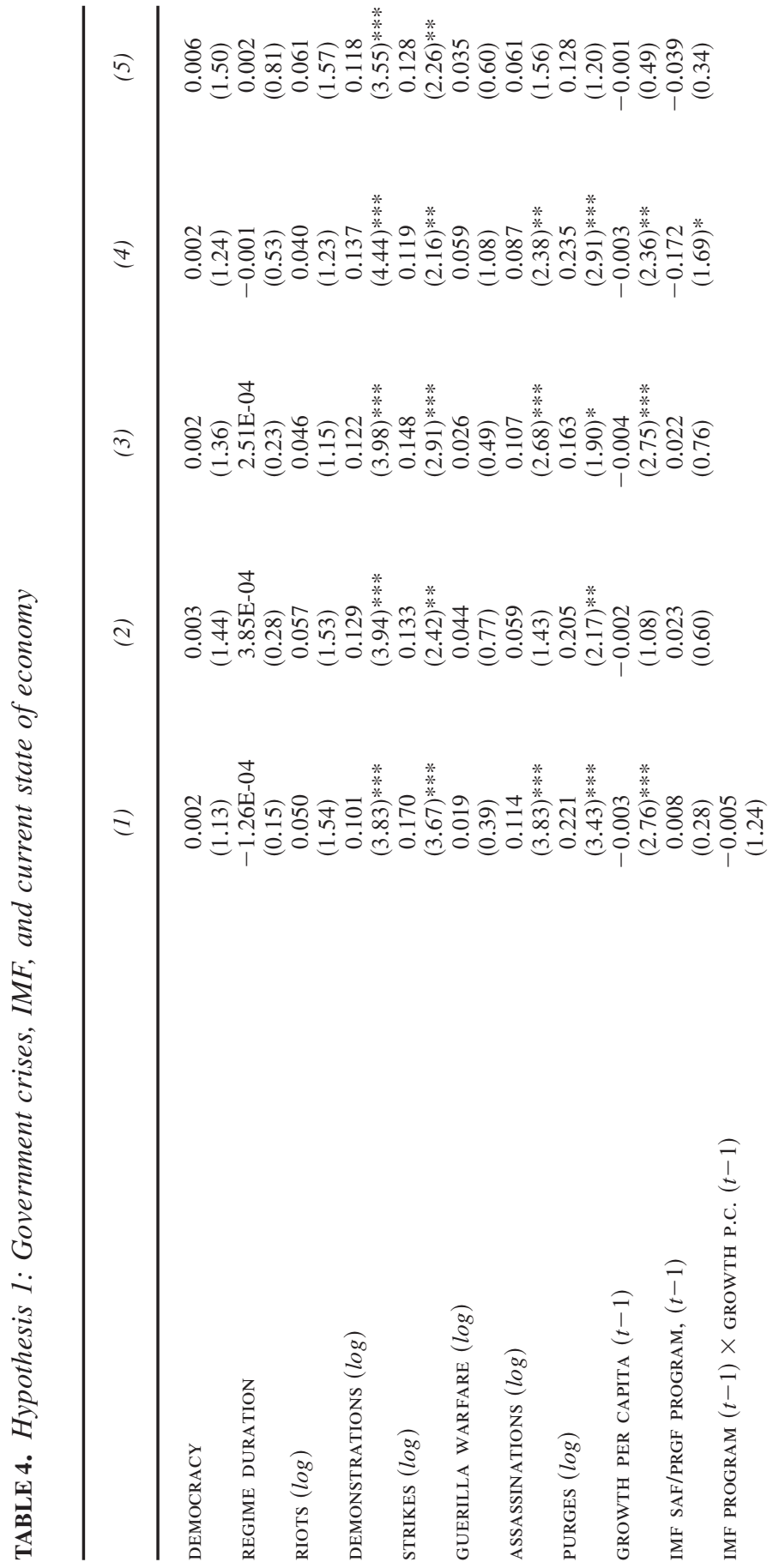




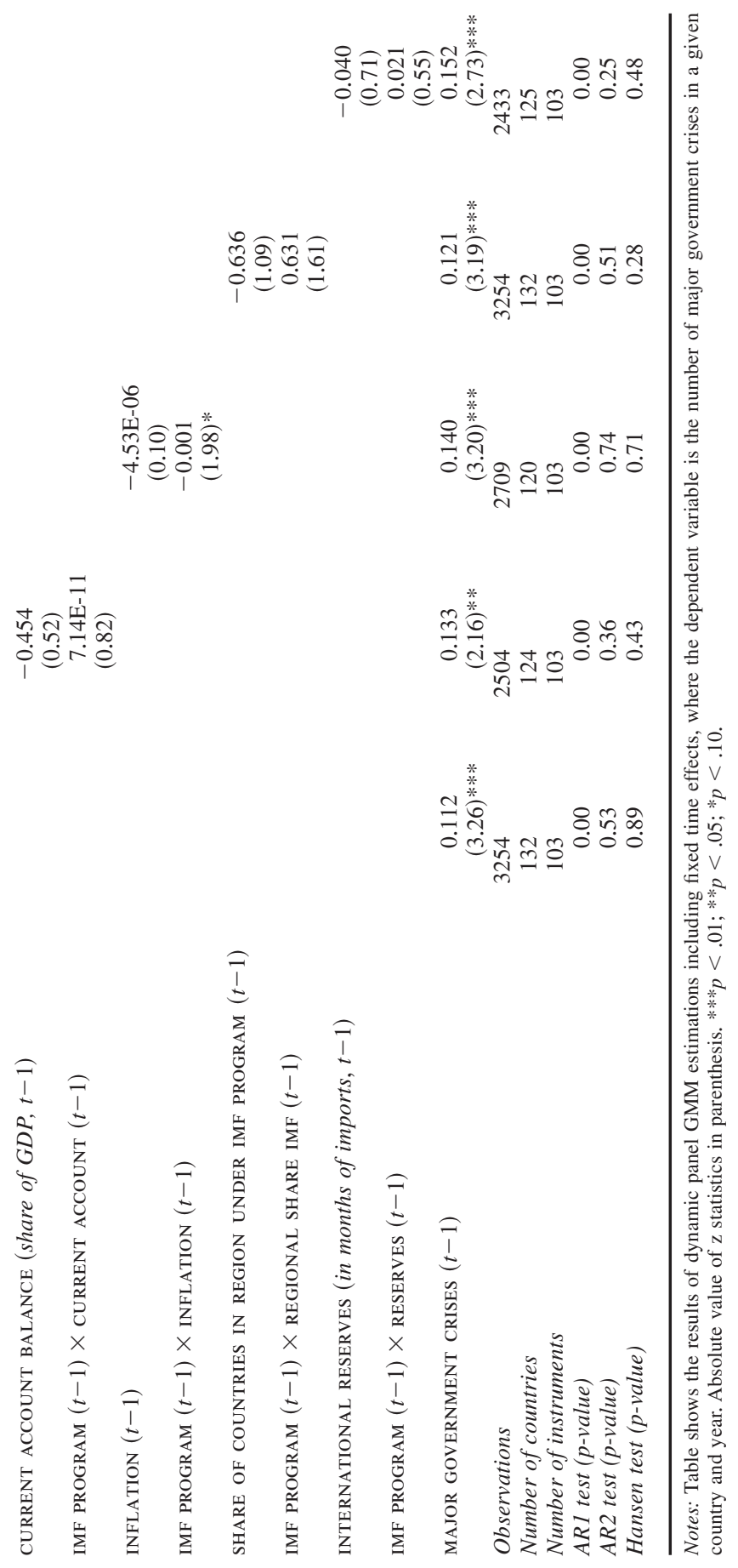




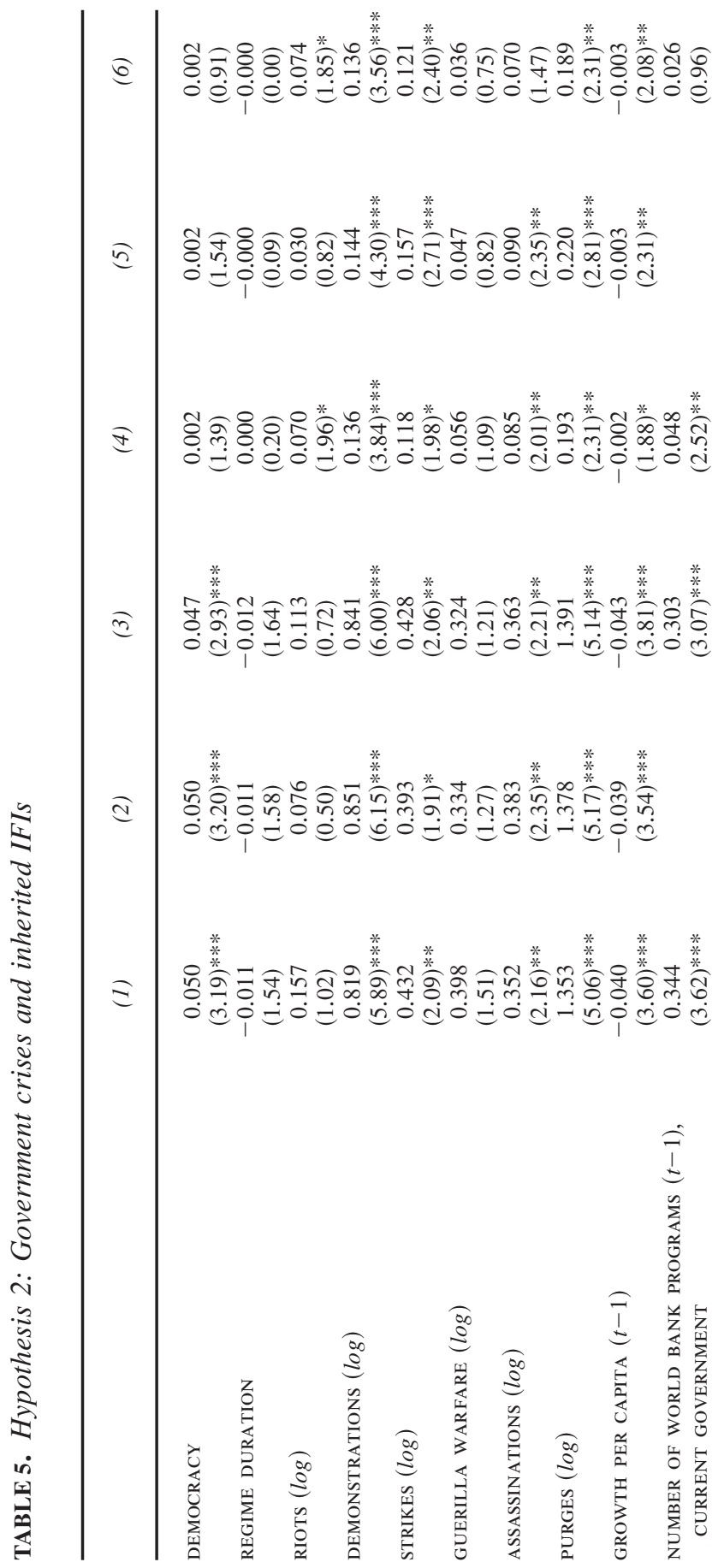




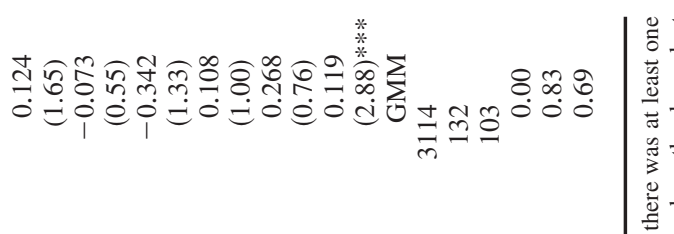

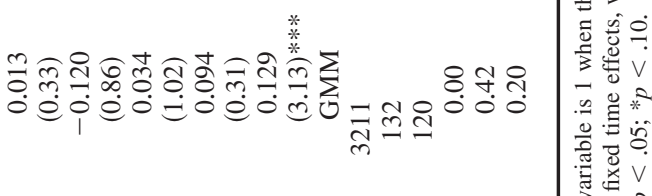

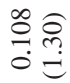

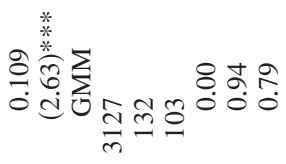

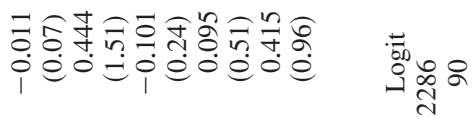

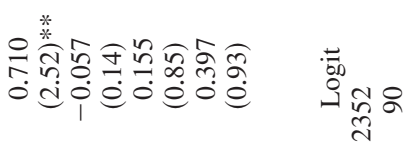

$$
\begin{aligned}
& \text { ì }
\end{aligned}
$$

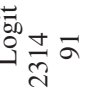

$$
\begin{aligned}
& \text { 䟚 } *
\end{aligned}
$$

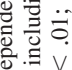

$$
\begin{aligned}
& \text {. } \\
& \text { E. }
\end{aligned}
$$

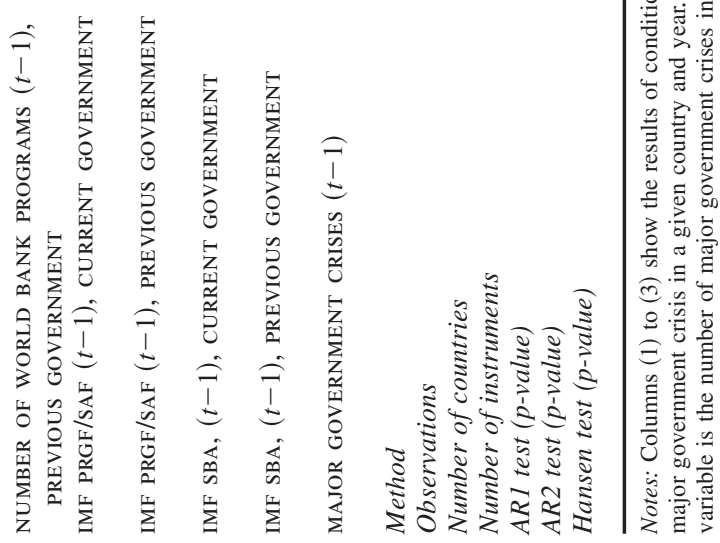


In summary, there is some evidence to support H1. The state of the economy does have an effect on the impact of the IFIs' programs. However, rather than being able to profit from potentially successful programs, governments face an increased risk of entering a crisis if they remain under an IFI program once the economy picks up. Again, we also added disbursements to the regressions and interacted disbursements with the variables measuring the state of the economy. Given that neither the disbursement variables nor the interactions were significant at conventional levels, we do not report them in the table. It seems that the mere existence of a program, rather than the actual loan size, might help citizens evaluate their government's competence.

Finally, we investigate whether, and to what extent, governments can blame their predecessors for the implementation of an IFI program, thereby avoiding the increased risk of a crisis as a consequence of the program $(\mathrm{H} 2)$. We therefore separate our IFI variables in two groups of arrangements. The first group has been negotiated by the preceding government, so that the current government cannot fully be blamed for their existence. The second group contains programs that the government itself agreed to, and is thus fully responsible for.

The results of Table 5 are in line with our hypothesis. Only programs concluded by the current government affect crisis probability. ${ }^{54}$ This is true for World Bank programs according to all specifications (at least at the 10 percent level of significance) and for the IMF's SAF/PRGF programs according to the logit estimates when the World Bank variables are excluded..$^{55}$ IMF and World Bank arrangements negotiated by preceding governments do not affect crisis probability in any specification. The corresponding marginal effects (again evaluated at the mean of all explanatory variables and with the fixed effects set to 0 ) are 8.4 percent and 7.6 percent for the World Bank (columns (1) and (3), respectively) and 17.0 percent for the IMF (column 2).$^{56}$ When we add disbursements to the regressions, the coefficients are again insignificant, and the results remain unchanged (not shown in the table). Unsurprisingly, the signaling effect of IMF and World Bank programs seems to be associated with the existence of the program, rather than the size of the loan itself. Only governments responsible for the conclusion of the program seem to be punished, while those inheriting a program are not. ${ }^{57}$

54. Note that about one fourth of both World Bank and IMF programs are inherited programs.

55. When we include the IMF's SBA programs and split them into inherited and self-initiated agreements we find both coefficients to be statistically insignificant at conventional levels. Their inclusion leaves our findings qualitatively unchanged.

56. The IV probit estimations yield very similar results that are not included in the table but available on request.

57. We also tested for the stability of the IFIs' effects over time, including a dummy for the postCold War period and interacting this dummy with our IMF and World Bank-related variables. In none of the regressions did the interaction term turn out to be significant (in the nonlinear regressions: at the mean of the variables). 


\section{Conclusion}

According to our results, structural adjustment arrangements significantly increase the probability of major government crises. For the World Bank, this finding does not depend on the method of estimation, while the impact of the IMF is not robust to controlling for endogeneity. We also find that governments face an increased risk of entering a crisis if they remain under the IFIs' programs when the economy performs better. For the World Bank, this is true for the level of international reserves and the size of the current account balance; regarding the IMF, inflation is important. Finally, only programs concluded by the current government affect crises, while those inherited by preceding governments do not. The evidence is thus in line with a signaling model where IFI programs can be used by voters to infer the competence of politicians. ${ }^{58}$

Overall, the significant effects arise for the IFIs' programs, but not for their disbursements. Following the interpretation of Boockmann and Dreher, conditionality and advice seem to be more important than moral hazard due to increased budgetary leeway, for example. ${ }^{59}$ The existence of a program, rather than the size of a loan, seems to be the signal used by people to gauge the competence of their government.

Our results bear important policy implications. On average, countries increase the risk of entering a crisis after turning to the World Bank, but not to the IMF. For both organizations, the development of the economy over the period of a program affects crisis probability. This insight might help governments in choosing the right time to exit such programs. On average, governments can blame the IFIs for unpopular policies when the economy is experiencing tougher times. However, once a recovery is on its way, governments might consider terminating existing arrangements in order to avoid a crisis. Consider Bolivia: the government first agreed to IMF and World Bank programs in 1986, when inflation amounted to 276 percent and reserves covered 5.3 months of imports. The government remained under IMF and World Bank programs and a crisis ensued, even though inflation had fallen to 2.2 percent by the year 2000 and reserves had increased to 6.4 months of imports. According to our estimates, the Bolivian government would have benefited from terminating the program when its economic data improved. Given that the government itself started the latest arrangements in 1998, voters might have held the government accountable. The privatization of water utilities in Cochabamba, for example, was no longer tolerated by large shares of the population and a major government crisis resulted in 2000 .

While our results may entail advice for selfish governments on whether or not to turn to the IMF and the World Bank, there is still no sharp discrimination between two alternative hypotheses. First, instability might increase because program terms are onerous and damage the economy, thereby creating a situation that damages

58. Dreher 2004.

59. Boockmann and Dreher 2003. 
the government. Second, crises might occur because the program reveals the poor quality of government policies. If the probability of a crisis increases due to program conditions that produce negative socioeconomic outcomes, it should not matter whether a government inherited a program or not. If we assume that the IMF and the World Bank do not change conditions when a new government is elected, our finding that only programs concluded by the current government increase the probability of crises, while those inherited do not, would point in the direction of the signaling model. However, if governments that inherit programs are less likely to implement program conditions agreed to by their predecessors (or the IFIs are less likely to insist on implementation), the issue remains unresolved. Further research incorporating conditionality would be required. ${ }^{60}$

With the data at hand, we can only speculate on the exact channels that drive our findings. Is it the disparate impact of programs on interest groups? The poor design of structural adjustment policies or negative reactions from financial markets? While the welfare implications of these alternatives are fundamentally different, they imply the same unwelcome consequence from the government's perspective.

A potential avenue for future research could concentrate on modelling the detailed channels underlying the results of this paper. On the theory side, we suggest developing the microfoundations underlying the negative effect of the IFIs' programs on government crises further. More theory is needed on how these programs can transmit into government crises. With respect to testing this more fine-grained theory, we suggest collecting more detailed data on the design of the IFIs' programs. By using data on conditionality and resources invested by the IFIs to prepare and supervise their projects, we would be able to differentiate between the effects of conditionality and advice. ${ }^{61}$

TABLE A1. List of variables, definitions, and sources

\begin{tabular}{llc}
\hline Variable & \multicolumn{1}{c}{ Definition } & Source \\
\hline MAJOR GOVERNMENT CRISES & $\begin{array}{l}\text { Any rapidly developing situation } \\
\text { that threatens to bring the downfall } \\
\text { of the present regime, excluding } \\
\text { situations of revolt aimed at such } \\
\text { overthrow. }\end{array}$ & $\begin{array}{c}\text { Databanks International } \\
(2005)\end{array}$
\end{tabular}

60. We thank an anonymous reviewer for pointing this out.

61. Such data exist but are usually not shared by the IFIs with outside researchers. For example, the World Bank collects detailed information on staff preparation and supervision of its projects, and the conditions included in its programs. The IMF's Monitoring of Fund Arrangements (MONA) database provides detailed information on IMF conditionality, and compliance with it. This database has only been publically available since 2002. Available at 〈www.imf.org/external/np/pdr/mona/index.aspx , accessed 2 November 2011. 
TABLE A1. (Continued)

\begin{tabular}{|c|c|c|}
\hline Variable & Definition & Source \\
\hline IMF SAF/PRGF PROGRAM & $\begin{array}{l}\text { Dummy variable that is } 1 \text { if an IMF } \\
\text { program under the Structural } \\
\text { Adjustment Facility or Poverty } \\
\text { Reduction and Growth Facility has } \\
\text { been in effect for at least five } \\
\text { months in a certain year, and } 0 \\
\text { otherwise. }\end{array}$ & IMF Annual Reports \\
\hline IMF SBA PROGRAM & $\begin{array}{l}\text { Dummy variable that is } 1 \text { if an IMF } \\
\text { Stand-by Agreement has been in } \\
\text { effect for at least five months in a } \\
\text { certain year, and } 0 \text { otherwise. }\end{array}$ & IMF Annual Reports \\
\hline WORLD BANK PROGRAMS & $\begin{array}{l}\text { Variable counting the number of } \\
\text { World Bank programs in effect for } \\
\text { at least five months in a certain } \\
\text { year. Includes programs given for } \\
\text { structural adjustment, according to } \\
\text { the definition from the World } \\
\text { Bank's website. }\end{array}$ & www.worldbank.org \\
\hline $\begin{array}{l}\text { IDA DISBURSEMENTS } \\
\text { (share of GDP) }\end{array}$ & $\begin{array}{l}\text { Drawings by the borrower on loan } \\
\text { commitments from the IDA in } \\
\text { current US\$ divided by GDP in } \\
\text { current US\$. }\end{array}$ & $\begin{array}{l}\text { World Bank, Global } \\
\text { Development Finance }\end{array}$ \\
\hline $\begin{array}{l}\text { IBRD DISBURSEMENTS } \\
\text { (share of } G D P)\end{array}$ & $\begin{array}{l}\text { Drawings by the borrower on loan } \\
\text { commitments from the IBRD in } \\
\text { current US\$ divided by GDP in } \\
\text { current US\$. }\end{array}$ & $\begin{array}{l}\text { World Bank, Global } \\
\text { Development Finance }\end{array}$ \\
\hline $\begin{array}{l}\text { IMF SAF/PRGF DISBURSEMENTS } \\
\text { (share of GDP) }\end{array}$ & $\begin{array}{l}\text { Disbursements of loans and credits } \\
\text { through the Poverty Reduction and } \\
\text { Growth Facility and IMF Trust } \\
\text { Fund in current US\$ divided by } \\
\text { GDP in current US\$. }\end{array}$ & IMF Annual Reports \\
\hline $\begin{array}{l}\text { IMF SBA DISBURSEMENTS } \\
\text { (share of GDP) }\end{array}$ & $\begin{array}{l}\text { Disbursements of loans and credits } \\
\text { through Stand-by Agreements in } \\
\text { current US\$ divided by GDP in } \\
\text { current US\$. }\end{array}$ & IMF Annual Reports \\
\hline DEMOCRACY & $\begin{array}{l}\text { Polity } 2 \text { score, represents the differ- } \\
\text { ence between a country's democracy } \\
\text { and autocracy score. Ranges from } \\
-10 \text { to } 10 \text { with high numbers indi- } \\
\text { cating higher levels of democracy. }\end{array}$ & $\begin{array}{l}\text { Marshall, Gurr, and } \\
\text { Jaggers } 2010\end{array}$ \\
\hline REGIME DURATION & $\begin{array}{l}\text { The number of years that a political } \\
\text { regime is in place. }\end{array}$ & $\begin{array}{l}\text { Marshall, Gurr, and } \\
\text { Jaggers } 2010\end{array}$ \\
\hline RIOTS & $\begin{array}{l}\text { Any violent demonstration or clash } \\
\text { of more than } 100 \text { citizens involving } \\
\text { the use of physical force. }\end{array}$ & $\begin{array}{l}\text { Databanks International } \\
\quad 2005\end{array}$ \\
\hline DEMONSTRATIONS & $\begin{array}{l}\text { Any peaceful public gathering of at } \\
\text { least } 100 \text { people for the primary } \\
\text { purpose of displaying or voicing } \\
\text { their opposition to government } \\
\text { policies or authority, excluding } \\
\text { demonstrations of a distinctly } \\
\text { antiforeign nature. }\end{array}$ & $\begin{array}{l}\text { Databanks International } \\
2005\end{array}$ \\
\hline
\end{tabular}


TABLE A1. (Continued)

\begin{tabular}{|c|c|c|}
\hline Variable & Definition & Source \\
\hline STRIKES & $\begin{array}{l}\text { Any strike of } 1,000 \text { or more indus- } \\
\text { trial or service workers that involves } \\
\text { more than one employer and that is } \\
\text { aimed at national government poli- } \\
\text { cies or authority. }\end{array}$ & $\begin{array}{l}\text { Databanks International } \\
2005\end{array}$ \\
\hline GUERILLA WARFARE & $\begin{array}{l}\text { Any armed activity, sabotage, or } \\
\text { bombings carried on by } \\
\text { independent bands of citizens or } \\
\text { irregular forces and aimed at the } \\
\text { overthrow of the present regime. }\end{array}$ & $\begin{array}{l}\text { Databanks International } \\
2005\end{array}$ \\
\hline ASSASSINATIONS & $\begin{array}{l}\text { Any politically motivated murder or } \\
\text { attempted murder of a high } \\
\text { government official or politician. }\end{array}$ & $\begin{array}{l}\text { Databanks International } \\
2005\end{array}$ \\
\hline PURGES & $\begin{array}{l}\text { Number of systematic repressions } \\
\text { (or eliminations) by jailing or } \\
\text { execution of political opposition } \\
\text { within the rank of the regime or the } \\
\text { opposition. }\end{array}$ & $\begin{array}{l}\text { Databanks International } \\
\quad 2005\end{array}$ \\
\hline ECONOMIC GROWTH PER CAPITA & $\begin{array}{l}\text { Real GDP growth per capita in } \\
\text { constant (2000) US\$. }\end{array}$ & World Bank 2006 \\
\hline INFLATION & $\begin{array}{l}\text { Inflation, consumer prices (annual } \\
\text { percent). }\end{array}$ & World Bank 2006 \\
\hline INTERNATIONAL RESERVES & $\begin{array}{l}\text { International reserves in months of } \\
\text { imports. }\end{array}$ & World Bank 2006 \\
\hline AVG WB PROGRAMS IN REGION & $\begin{array}{l}\text { The average number of World Bank } \\
\text { programs in the same geographic } \\
\text { region (excluding the respective } \\
\text { country). }\end{array}$ & www.worldbank.org \\
\hline $\begin{array}{l}\text { SHARE OF COUNTRIES IN } \\
\text { REGION UNDER IMF PROGRAM }\end{array}$ & $\begin{array}{l}\text { The share of countries which are } \\
\text { under an IMF program in the same } \\
\text { geographic region (excluding the } \\
\text { respective country). }\end{array}$ & Author \\
\hline $\begin{array}{l}\text { CURRENT ACCOUNT BALANCE } \\
\text { (share of GDP) }\end{array}$ & $\begin{array}{l}\text { Current account balance in current } \\
\text { US\$ divided by GDP in current } \\
\text { US\$. }\end{array}$ & World Bank 2006 \\
\hline
\end{tabular}

TABLE A2. Summary statistics

\begin{tabular}{lccccc}
\hline Variable & & & $\begin{array}{l}\text { Standard } \\
\text { deviation }\end{array}$ & Minimum & Maximum \\
\hline MAJOR GOVERNMENT CRISES & 4629 & 0.15 & 0.48 & 0 & 7 \\
CRISIS DUMMY & 4629 & 0.11 & 0.32 & 0 & 1 \\
NUMBER OF WORLD BANK PROGRAMS & 5565 & 0.29 & 0.73 & 0 & 7 \\
IMF SAF/PRGF PROGRAM & 5565 & 0.10 & 0.30 & 0 & 1 \\
IMF SBA PROGRAM & 5565 & 0.13 & 0.34 & 0 & 1 \\
IDA DISBURSEMENTS (share of GDP) & 4605 & $1.1 \mathrm{E}-03$ & $1.1 \mathrm{E}-03$ & 0 & 0.02
\end{tabular}


TABLE A2. (Continued)

\begin{tabular}{|c|c|c|c|c|c|}
\hline Variable & Observations & Mean & $\begin{array}{l}\text { Standard } \\
\text { deviation }\end{array}$ & Miniтит & Махітит \\
\hline IBRD DISBURSEMENTS ( $\%$ of $G D P$ ) & 4450 & $1.3 \mathrm{E}-03$ & $3.6 \mathrm{E}-03$ & 0 & 0.08 \\
\hline $\begin{array}{l}\text { IMF SAF/PRGF DISBURSEMENTS } \\
\quad(\% \text { of } G D P)\end{array}$ & 3446 & $8.6 \mathrm{E}-04$ & 4.3E-03 & 0 & 0.16 \\
\hline $\begin{array}{l}\text { IMF SBA DISBURSEMENTS } \\
\quad(\% \text { of } G D P)\end{array}$ & 4605 & $1.0 \mathrm{E}-03$ & $5.5 \mathrm{E}-03$ & 0 & 0.20 \\
\hline DEMOCRACY & 4013 & -1.35 & 6.95 & -10 & 10 \\
\hline REGIME DURATION & 3899 & 15.57 & 17.39 & 0 & 105 \\
\hline RIOTS $(\log )$ & 4629 & 0.15 & 0.43 & 0 & 3.30 \\
\hline DEMONSTRATIONS $(l o g)$ & 4629 & 0.22 & 0.51 & 0 & 3.30 \\
\hline STRIKES $(\log )$ & 4629 & 0.07 & 0.26 & 0 & 2.08 \\
\hline GUERILLA WARFARE $(l o g)$ & 4629 & 0.12 & 0.30 & 0 & 3.56 \\
\hline ASSASSINATIONS $(\log )$ & 4629 & 0.10 & 0.34 & 0 & 3.26 \\
\hline PURGES $(\log )$ & 4629 & 0.04 & 0.20 & 0 & 2.30 \\
\hline GROWTH PER CAPITA $(t-1)$ & 4420 & 1.44 & 6.77 & -50.49 & 89.83 \\
\hline INFLATION & 3542 & 56.77 & 562.24 & -21.68 & 23773 \\
\hline INTERNATIONAL RESERVES & 3365 & 3.47 & 3.05 & -0.09 & 27.08 \\
\hline AVG. WB PROJECTS IN REGION & 5406 & 0.29 & 0.30 & 0 & 1.33 \\
\hline $\begin{array}{l}\text { SHARE OF COUNTRIES IN REGION } \\
\text { UNDER IMF PROGRAM }\end{array}$ & 5406 & 0.10 & 0.15 & 0 & 0.54 \\
\hline $\begin{array}{l}\text { CURRENT ACCOUNT BALANCE } \\
(\% \text { of } G D P)\end{array}$ & 3181 & -0.05 & 0.11 & -2.40 & 0.57 \\
\hline
\end{tabular}

\section{References}

Ai, Chunrong, and Edward C. Norton. 2003. Interaction Terms in Logit and Probit Models. Economics Letters 80 (1):123-29.

Beck, Nathaniel, Jonathan N. Katz, and Richard Tucker. 1998. Taking Time Seriously: Time-SeriesCross-Section Analysis with a Binary Dependent Variable. American Journal of Political Science 42 (4):1260-88.

Boockmann, Bernhard, and Axel Dreher. 2003. The Contribution of the IMF and the World Bank to Economic Freedom. European Journal of Political Economy 19 (3):633-49.

Broz, J. Lawrence. 2002. Political System Transparency and Monetary Commitment Regimes. International Organization 56 (4):861-87.

Buira, Ariel. 2002. An Analysis of IMF Conditionality. Working Paper 104. Oxford, UK: Department of Economics, University of Oxford. Available at 〈http://www.economics.ox.ac.uk/research/WP/ PDF/paper104.pdf $\rangle$. Accessed 1 November 2011.

Caffentzis, George, and Silvia Federici. 2001. A Brief History of Resistance to Structural Adjustment. In Democratizing the Global Economy: The Battle Against the World Bank and the IMF, edited by Kevin Danaher, 139-44. Monroe, Maine: Common Courage Press.

Databanks International. 2005. Cross-National Time-Series Data Archive, 1815-2003. Binghamton, N.Y.: Databanks International.

Drazen, Allan. 2002. Conditionality and Ownership in IMF Lending: A Political Economy Approach. IMF Staff Papers 49 (IMF Annual Research Conference):36-67.

Dreher, Axel. 2004. The Influence of IMF Programs on the Re-election of Debtor Governments. Economics and Politics 16 (1):53-76. 
Dreher, Axel, and Jan-Egbert Sturm. 2012. Do the IMF and the World Bank Influence Voting in the UN General Assembly? Public Choice 151 (1):363-97.

Dreher, Axel, and Roland Vaubel. 2004. Do IMF and IBRD Cause Moral Hazard and Political Business Cycles? Evidence from Panel Data. Open Economies Review 15 (1):5-22.

Eslava, Marcela. 2006. The Political Economy of Fiscal Policy: Survey. Working Paper 583. Washington, D.C.: Inter-American Development Bank.

Gassebner, Martin, and Richard Jong-A-Pin. 2007. Determinants of Government Crisis. Unpublished manuscript, ETH Zurich, Switzerland.

Greene, William. 2010. Testing Hypotheses About Interaction Terms in Nonlinear Models. Economics Letters 107 (2):291-96.

Kilby, Christopher. 2009. The Political Economy of Conditionality: An Empirical Analysis of World Bank Loan Disbursements. Journal of Development Economics 89 (1):51-61.

- 2011. Informal Influence in the Asian Development Bank. Review of International Organizations 6 (3-4):223-57.

Killick, Tony. 1995. IMF Programmes in Developing Countries: Design and Impact. London: Routledge.

Marchesi, Silvia, and Laura Sabani. 2007. IMF Concern for Reputation and Conditional Lending Failure: Theory and Empirics. Journal of Development Economics 84 (2):640-66.

Marchesi, Silvia, Laura Sabani, and Axel Dreher. 2011. Read My Lips: The Role of Information Transmission in Multilateral Reform Design. Journal of International Economics 84 (1):86-98.

Marchesi, Silvia, and Emanuela Sirtori. 2011. Is Two Better than One? The Effects of IMF and World Bank Interaction on Growth. Review of International Organizations 6 (3-4):287-306.

Marshall, Monty G., Ted Robert Gurr, and Keith Jaggers. 2010. Polity IV Project: Political Regime Characteristics and Transitions, 1800-2009. Dataset Users' Manual. Center for Systemic Peace. Available at 〈http://www.systemicpeace.org/inscr/p4manualv2009.pdf $\rangle$. Accessed 31 October 2011.

Moser, Christoph, and Jan-Egbert Sturm. 2011. Explaining IMF Lending Decisions After the Cold War. Review of International Organizations 6 (3-4):307-40.

Sattler, Thomas, and Stefanie Walter. 2010. Monetary Credibility vs. Voter Approval: Political Institutions and Exchange-Rate Stabilization During Crises. Economics and Politics 22 (3):392-418.

Smith, Alastair, and James Raymond Vreeland. 2006. The Survival of Political Leaders and IMF Programs. In Globalization and the Nation State: The Impact of the IMF and the World Bank, edited by Gustav Ranis, James Raymond Vreeland, and Stephen Kosack, 263-89. New York: Routledge.

Staiger, Douglas, and James H. Stock. 1997. Instrumental Variables Regression with Weak Instruments. Econometrica 65 (3):557-86.

Steinwand, Martin C., and Randall W. Stone. 2008. The International Monetary Fund: A Review of the Recent Evidence. Review of International Organizations 3 (2):123-49.

Vreeland, James Raymond. 1999. The IMF: Lender of Last Resort or Scapegoat? Leitner Working Paper 1999-03. New Haven, Conn.: Department of Political Science, Yale University. Available at 〈http://www.yale.edu/leitner/resources/docs/1999-03.pdf〉. Accessed 31 October 2011.

- 2003. The IMF and Economic Development. Cambridge: Cambridge University Press.

2006. IMF Program Compliance: Aggregate Index Versus Policy Specific Research Strategies. Review of International Organizations 1 (4):359-78.

World Bank. 2005. Review of World Bank Conditionality: Issues Note. Washington, D.C.: World Bank. 2006. World Development Indicators 2006. Washington, D.C.: World Bank. 